\section{The Human Nature of Human Nature}

\author{
Theories that human behavior is based on instincts \\ violate the findings of developmental biopsychology.
}

Leon Eisenberg

Understanding the nature of man and his works has become a precondition for the survival of our species, as well as for the enhancement of the flowering of human individuality. The search for that understanding is the central purpose of the university and the source of its relevance to society. After a period of public worship that verged on idolatry, universities have become the target of sustained and bitter attack. Yesterday's idolatry may have been a worship of false gods: credentials to an affluent life, technological virtuosity with little concern for its ends, and a meritocracy that excluded ethnic and linguistic minorities. But today's exorcism is aimed at false devils: the freedom to explore unpopular ideas, the transmission of our cultural heritage, and the support of fundamental research. The young excoriate universities for their corruption by the Establishment, the Establishment for their receptivity to the new, and governments for their failure to guarantee docile citizens.

The criticism, if indiscriminate and shrill, is not without substance; it must be heeded if the universities are to ex-

The author is professor of psychiatry at $\mathrm{Har}$ vard Miedical School and chief of psychiatry at the Massachusetts General Hospital, Boston 02114. This artic!e is based on an address presented at Faculty of Medicine Day, McGill University Sesquicentennial Celebration, Montreal, Canada, 1 October 1971. cise the accretions of age. Like others, those connected with the university find it easiest to do what they have done before. Yet, if there is a single leitmotiv of our time, it is a constantly accelerating rate of change. With each decade, scientific findings translated into technology radically reshape the way we live. Technical capacity has been the ruling imperative, with no reckoning of cost, either ecological or personal. If it could be done, it has been done. Foresight has lagged far behind craftsmanship. At long last we are beginning to ask, not can it be done, but should it be done? The challenge is to our ability to anticipate the second- and thirdorder consequences of interventions in the ecosystem before the event, not merely to rue them afterward. The power of our technology so foreshortens the time between its application and the possibility of its correction that we must learn to think through before we act out (l).

If we were to understand each other even half as well as we comprehend the energy of the stars, we might yet spare ourselves the horrors we face from traducing those energies into weapons that endanger all life. If psychiatry cannot yet provide a firm basis for that understanding, it may nonetheless be of service if it dispels the myths and the pseudoknowledge that obscure the search for truth.

\section{Self-Fulfilling Prophecies}

The title of this article implies its conclusion: that there is to human nature a nature that is other than naked ape, actuated by territorial imperatives and impelled by aggressive instincts. Such a conclusion must seem outrageously optimistic in an era in which Americans "waste" Vietnamese, in which West Pakistani massacre their countrymen to the East-but there is no need to retell the litany of violence. How, in the teeth of this "evidence," can we disbelieve Morris, Ardrey, or Lorenz (2)? How can we challenge Freud, his illusions of civilization shattered by the barbarities of World War I when he wrote (3): "The very emphasis of the Commandment: Thou shalt not kill, makes it certain that we are descended from an endlessly long chain of generations of murderers whose love of murder was in their blood as it is perhaps also in our own ..."? Or again (4): "The tendency to aggression is an innate, independent, instinctual disposition in man ..."? How, indeed?

This is no mere academic exercise, of concern only to students of behavior. The planets will move as they always have, whether we adopt a geocentric or a heliocentric view of the heavens. It is only the equations we generate to account for those motions that will be more or less complex; the motions of the planets are sublimely indifferent to our earthbound astronomy. But the behavior of men is not independent of the theories of human behavior that men adopt. One example may serve to explicate this thesis.

So long as the "nature" of insanity was thought to be violent, and so long as the insane were chained, beaten, and locked in cells, madmen raged and fumed. With the introduction of the "moral treatment" of the insane at the beginning of the 19th century, violence in mental asylums markedly abated (5). A century later, the "nature" of insanity was perceived as social incompetence: the sick were "protected" from stress, and the institution assumed 
responsibility for all decision-making. Misguided benevolence stripped the patient of adult status and generated automaton-like compliance; the result was the chronicity of the back wards of our state hospitals. A generation ago, the concept of the therapeutic environment, with its rediscovery of selfgovernment and personal responsibility as the bases for attaining competence, began to reverse the cycle of self-perpetuating hospitalization. This led to a decline in what had been a steadily rising population if ${ }^{\text {if }}$ U.S. mental hospitals, a decline : began before the era of psychotropic drugs (6). Do not mistake me. Psychosis is no mere social convention; it has a psychobiological existence independent of systems of belief. But its manifestations and its course are profoundly influenced by the social field in which the patient and his caretakers operate. Belief systems act no less profoundly on the remainder of mankind. The doctor's very presence relieves pain. Teachers' expectations govern pupils' performance. The citizens' confidence in the benevolence of the social order maintains its stability.

What we believe of man affects the behavior of men, for it determines what each expects of the other. Theories of education, of political science, of economics, and the very policies of governments are based on implicit concepts of the nature of man. Is he educable? Is he actuated only by selfinterest? Is he a creature of such dark lusts that only submission to sovereign authority can save him from himself?

What we choose to believe about the nature of man has social consequences. Those consequences should be weighed in assessing the belief we choose to hold, even provisionally, given the lack of compelling proof for any of the currently fashionable theories. In insisting on an assessment of potential outputs in addition to a critique of inputs, $I$ do not suggest that we ignore scientific evidence when it does not suit our fond wishes. Any hope of building a better world must begin with a tough-minded appraisal of the facts that are to be had. The thrust of my argument is that there is no solid foundation to the theoretical extrapolation of the instinctivists, the ethologists, the behaviorists, or the psychoanalysts, despite the special pleading that often is so seductive to those eager for a "real science" of behavior. Further to the point, belief helps shape actuality because of the self-fulfilling character of social prophecy. To believe that man's aggressiveness or territoriality is in the nature of the beast is to mistake some men for all men, contemporary society for all possible societies, and, by a remarkable transformation, to justify what is as what needs must be; social repression becomes a response to, rather than a cause of, human violence. Pessimism about man serves to maintain the status quo. It is a luxury for the affluent, a sop to the guilt of the politically inactive, a comfort to those who continue to enjoy the amenities of privilege. Pessimism is too costly for the disenfranchised; they give way to it at the price of their salvation. No less clearly, the false "optimism" of the unsubstantiated claims made for behavioral engineering, claims that ignore biological variation and individual creativity, foreclose man's humanity.

What is known about the power of the social-psychological determinants of human behavior compels the conclusion that the set of axioms for a theory of human nature must include a Kantian categorical imperative: men and women must believe that mankind can become fully human in order for our species to attain its humanity. Restated, a soberly optimistic view of man's potential (based on recognition of mankind's attainments, but tempered by knowledge of its frailties) is a precondition for social action to make actual that which is possible.

\section{Innate Schemata and Racial Purity}

Some readers may object to "politicizing" what should be a "scientific" discussion. My contention is that it is necessary to make overt what is latent in treatises on the "innate" nature of man. Consider, for example, Lorenz. Surely, those who have been charmed by his film of himself leading, like a mother goose, a brood of greylag geese about the farmyard will recoil from identifying his works as political. What is political about inborn schemata, innate releasing mechanisms, species-specific mating patterns, and the like? A great deal, as his own writings make clear, when such concepts, of dubious applicability to animal behavior itself (7), are transposed directly to man without attending to species differences and to phyletic levels. Lorenz found it possible to write, in 1940 , that the effects of civilization on human beings parallel those of domestication in animals (8). In domesticated animals, he argued, degenerative mutations result in the loss of species-specific releaser mechanisms responding to innate schemata that govern mating patterns and that serve in nature to maintain the purity of the stock. Similar phenomena are said to be an inevitable by-product of civilization unless the state is vigilant (8, pp. 56-75).

The only resistance which mankind of healthy stock can offer . . . against being penetrated by symptoms of degeneracy is based on the existence of certain innate schemata. . . Our species-specific sensitivity to the beauty and ugliness of members of our species is intimately connected with the symptoms of degeneration, caused by domestication, which threaten our race. .. Usually, a man of high value is disgusted with special intensity by slight symptoms of degeneracy in men of the other race. ... In certain instances, however, we find not only a lack of this selectivity . . . but even a reversal to being attracted by symptoms of degeneracy. . . . Decadent art provides many examples of such a change of signs. . . . The immensely high reproduction rate in the moral imbecile has long been established. . . . This phenomenon leads everywhere ... to the fact that socially inferior human material is enabled ... to penetrate and finally to annihilate the healthy nation. The selection for toughness, heroism, social utility ... must be accomplished by some human institution if mankind, in default of selective factors, is not to be ruined by domestication-induced degeneracy. The racial idea as the basis of our state has already accomplished much in this respect. The most effective race-preserving measure is ... the greatest support of the natural defenses. . . . We must-and shouldrely on the healthy feelings of our Best and charge them with the selection which will determine the prosperity or the decay of our people ... . [italics added].

Thus, it would appear, science warrants society's erecting social prohibitions in order to replace the degenerated innate schemata for racial purity. Lorenz's "scientific" logic justified Nazi legal restrictions against intermarriage with non-Aryans. The wild extrapolations from domestication to civilization, from ritualized animal courtship patterns to human behavior, from species to races, are so gross and unscientific, the conclusions so redolent of concentration camps, that further commentary should be superfluous. Perhaps it is impolite to recall in 1972 what was written in 1940 , but $I$, at least, find 1940 difficult to forget; indeed, I believe it should not be forgotten, lest we find ourselves in Or- 
well's 1984 for the very best of "scientific" reasons.

My position should not be misconstrued as condemning the study of comparative psychology or the search for biological determinants of human behavior as though such efforts were inherently fascist. What I do inveigh against is the formulation of pseudoscientific support for a priori social ideologies that are projected onto, not "found" in, nature. Such pseudoscience ignores species differences and phyletic levels and misrepresents analogy as homology. For example, attack behavior can be observed in organisms as varied as insect, bird, carnivore, ape, and man. In the first, it may be triggered by trace chemicals; in the second, by territorial defense, but only during the breeding season; in the third, by prey, but only if the appropriate internal state of arousal is present; in the fourth, by the appearance of a predator, if escape routes are unavailable and if the troop is threatened; and in man, by a mere verbal slur, if the social context and prior individual experience indicate attack as the socially appropriate response. The mere observation in divergent species of similar behavioral outcomes that fit the generic label "attack" justifies no conclusion about an underlying aggressive instinct, without detailed study of the conditions evoking, and the mechanisms governing, the behavior of each. Such "explanations" reify a descriptive label that has been indiscriminately applied to markedly different levels of behavioral organization, as though naming were the same as explaining.

\section{Teleology or Ontogenesis}

Indeed, reports on animal behavior (9) fail to support the concept of an aggressive instinct as an independent motivational force analogous to hunger. That is, there is no predictable periodicity, no measurable changes in internal parameters (such as glucose concentrations in the blood), and no evidence of a "need" to attack in the absence of provocative stimuli. This is not to deny that the ease with which, and the circumstances under which, attack is elicited differs among species, nor that hormones, notably androgens, may have a profound impact on the probability of a fight rather than a flight response in higher organisms (10). The characteristics of the spe- cies, the genetic endowment of the individual organism, its prior experience, and the immediate stimuli interact to produce the behavioral outcome. Similar outcomes may result from quite different underlying mechanisms; meaningful comparisons become possible only when the mechanisms have been identified.

Examples could be multiplied. At the most general level, the problem stems from a telic orientation: behavior is "explained" by its outcome, rather than by an analysis of its ontogenesis. The cause is assumed to exist preformed in the organism as an "instinct" or innate pattern of behavior. The Platonic ideal is immanent in the organism. But where is it, when does it appear, and how does it come into being? Not even the most ardent instinctivist would any longer argue that the "instinct" for aggression or courtship rituals or nest building is in the fertilized egg. Yet it is confidently asserted that it must have been precoded and ready to go because it appears without any apparent requirement for prior learning.

Let us agree: behavior, like structure, is under genetic control. Animals of two species, reared in an identical environment, will nonetheless behave differently. The argument for innateness-in the sense of an inherited component-is compelling when the distribution of a given characteristic in an offspring generation can be predicted from knowledge of its distribution in the parent generation and the pattern of mating in that generation. However, the genetic evidence does not warrant the other sense in which innate is used-that is, developmental fixity, an imperviousness to environmental influences. Environment influences development by mechanisms that need have nothing to do with learning. For example, certain mutations in wing and eye structure of drosophila are temperature sensitive; if the eggs are maintained at $18^{\circ} \mathrm{C}$, the wing or eye develops normally, despite the presence of the mutant gene. This is hardly "learning," but it is evidence that expressivity depends on the environment. It does not make the characteristic any less genetic that its phenotypic expression is modified by temperature. But, by having discovered an array of such factors, the investigator has made a start at identifying the biochemical mechanisms underlying the action of genes. The central issue in the study of development is the problem of the interactions among the programmed but modifiable unfolding of the genome, its cellular envelope, and the surround. If the nucleus of a frog's intestinal cell transplanted into an enucleated frog's egg gives rise to a normal animal (11), then for all of the phenotypic differences between cell types, they share, as we knew they must, the same genetic apparatus, but an apparatus whose expressivity is under cytoplasmic as well as nuclear control.

Even in closely related species, differences are more revealing than similarities in elucidating the principles that govern behavior. Consider the study of bird vocalization, which, beyond its intrinsic fascination, may yet provide important clues to the understanding of sound imitation in man (12). It is a graphic example of a behavioral characteristic that displays remarkable ontogenetic differences in closely related species. Song sparrows, isolated from conspecifics and fosterreared by canaries, nonetheless acquire their own song. Yet meadowlarks, similarly isolated as fledglings, acquire the song of the particular foster species: wood pewees, yellowthroats, or red-winged blackbirds (13). Still different is the white-crowned sparrow, which must hear the adult model of its song during a "sensitive period" of development in order to acquire it; nonetheless, if the fledgling whitecrowned sparrow is simultaneously exposed to conspecifics and to two sympatric species, it "learns" only its own song. Once learned, the song persists, even if the adult is isolated. In the case of the goldfinch, the adult bird is able to learn new flight songs from other species (14). These few examples merely hint at the complexity of a growing field of inquiry. Precise attention to differences among species, the interrelationship of those differences with the ecology of the species, and the ultimate identification of the underlying neuromechanisms are what we will require for models that may have heuristic value in studying imitation behavior in man.

\section{Language: A Universal Human Trait}

Man's biological equipment is now, if ever, an essential topic of study. That equipment evolved over the 5 million years which elapsed between the 
australopithecine homonids and Homo sapiens; it provided the means for survival in an environment not yet altered by artifacts. The spread of our species and the rapid multiplication of our numbers in the past five millenia attest to the adaptability of that biological equipment to circumstances that did not exist when it was elaborated. It is becoming painfully evident that the changes we have wrought in the past five decades threaten our continuing survival under conditions of an exponential rate of population growth. It now becomes necessary to ask: How adaptable is man? Is mere perpetuation of the species, without concern for the quality of life, a sufficient criterion for man, even if it has been so for nature? Man's intelligence permits him the conscious choice of goals and so differentiates him from the rest of animate existence.

How, then, to discern the nature of man? Two general approaches suggest themselves-the comparative and the developmental. In the first, we compare and contrast the characteristics of men and women in the diverse societies that people this planet in the hope of extracting common denominators that express man's "essential nature"; in the second, we study the interaction between the infant and his social and biological environment as he grows to adulthood.

One trait common to man everywhere is language; in the sense that only the human species displays it, the capacity to acquire language must be genetic. As Chomsky has pointed out (15), among the unique aspects of human language learning are the child's ability to infer syntactical rules from a limited set of input samples and, in consequence, his extraordinary capacity to generate grammatical sentences that he has never heard. The language he speaks is determined by the language he hears, but the capacity for language must be a consequence of the genetic programming of brain networks as these respond to maturation and experience. Languages, insofar as they have been studied, appear to share fundamental structural characteristics, a universality that argues for an as-yetto-be-identified basis in common structures in the central nervous system. Recall the example of the white-crowned sparrow, which, though it must learn its song, is structured in such a way that its neural networks resonate only to a restricted set of external harmonic sequences. The data of linguistics suggest the possibility of a similar restriction on the form of language and the nature of grammatical structures; they imply limited variability in the neural schemata underlying language structures. Further refinement in our knowledge of these cognitive universals may yet enable us to propose models of neural mechanisms, which must then be sought experimentally.

Benzer (16) has brought the tools of genetic analysis to bear on behavioral mutants in drosophila. By the ingenious use of mosaics with phenotypic characteristics that permit the morphological identification of individual cells that carry or lack the mutant gene for phototaxis, he has found the source of the behavioral deviation to be structural abnormalities in the affected eye. In flies in which mosaicism is present within a single eye, histological techniques and single cell recordings can specify the deficit even more precisely. Cellular markers "provide powerful techniques for tracing the details of cell lineage during development, as well as genetic dissection of the functioning nervous system" (17). Even the limited complexity of the drosophila's central nervous system defies analysis by current techniques, but an important beginning has been made in relating genetically determined behavioral differences to underlying physiological mechanisms.

\section{The Diversity of Human Culture}

If language be one of the common features of human culture, even more remarkable are the diverse behaviors that cultures shape and are shaped by. What is labeled "masculine" in one culture and ascribed to the nature of maleness is regarded as "feminine" in another. Children are permitted uninhibited sexual expression and yet become monogamous adults in one culture; in another, preadult sexuality is heavily censored, whereas adult monogamy is privately violated while it is publicly proclaimed. Child care may be the responsibility of the nuclear family or of the group. The same Netsilik Eskimos who are loving and devoted parents can allow a female infant who is not "spoken for" in a prearranged marriiage to die unattended and ignored if she is not given a name and is thus, by definition, not yet human. The phenomenon of war is unknown to onesociety, appears in a second only under environmental stress, but is a lethal "game" without apparent material benefit in a third. Indeed, if we were to permit ourselves the argument that the more "primitive" the society, the more true to man's original nature the behavior displayed therein, we should have to conclude, as did Sahlins (18), that "war increases in intensity, bloodiness and duration ... through the evolution of culture, reaching its culmination in modern civilization." However agreeable, the argument for the pacific character of natural man, uncorrupted by the social order, is inadmissible; culture is as complete and complex in contemporary hunting and gathering tribes, despite their primitive technology, as it is in our own-man is man only in society.

What is striking in this very partial inventory is the remarkable diversity of the human behaviors evoked by various but viable cultures. If we explain the murderous raids of Brazilian Indians on the basis of an innate aggressive instinct, we shall have to invent an involved theory of repression, reaction formation, and sublimation to account for the peacefulness of the Eskimo. Would it not be far more parsimonious to begin with the assumption that men are by nature neither aggressive nor peaceful, but rather are fashioned into one or another as the result of a complex interaction between a widely, but not infinitely, modifiable set of biological givens and the shaping influences of the biological environment, the cultural envelope, and individual experience?

The very ubiquity of violence in Western society, however we explain its genesis historically, guarantees that children are surfeited with opportunities to learn violent behavior. The child sees that violence pays off; he is provided with adult models of violent behavior with whom to identify (television pales beside real life). Violence as an appropriate response to the resolution of intergroup conflict is sanctioned by national leaders. Reflect: the President of the United States intervened to prevent the immediate imprisonment of Calley, an officer convicted of mass murder in Vietnam by a jury of combat veterans. Consider: the Attorney General of the United States declined to press charges in the Kent State student murders. 
What are the ethical values these actions by national leaders convey? When violence is sanctioned, it will increase. It can be expected to generalize to situations not "intended" to come within official pardon. Learning may not account completely for human aggression, but the social forces in contemporary society that encourage its development are so evident (19) that preoccupation with hypothesized biological factors is almost quixotic.

Emphasis on the very marked differences among cultures may obscure what hás been, until recently, a conservative tradition within each. Children reared within a particular value system could expect to complete their days within that system. Values now change so rapidly that what a child is taught by his parents may no longer be functional when that child becomes an adolescent, let alone an adult. However wide the range of behaviors man can exhibit-evidenced by the comparison of one society with anotherthe task of developing adaptive attributes is very different when radically changed behaviors are required within an individual's lifetime rather than over the history of a people. The question now becomes, not how malleable is man, but how much change can a man undergo and still maintain his psychic integration?

Here we lack empirical data; there is no precedent for such rapid change. We confront the fundamental relevance of studies of child development. In a stable society, the price demanded by acculturation may or may not have been burdensome, but clearly it was bearable, or else that society would not have perpetuated itself. Studies of child development were important even then, if only to learn how to mitigate those burdens. But if we are to enable our children to cope with a world whose present shape we barely comprehend and whose future configurations we can only guess at dimly, then we are embarked on an enţerprise that is the very keystone of the sciences of survival.

\section{Man as His Own Chief Product}

I will forego detailing what we already know and ignore at the peril of the next generation: that the rapidly growing brain of fetus and infant is excruciatingly dependent on the ade- quacy of its nutrition (20); surely, no further amassing of scientific facts is needed to justify international commitment to the protection of the unborn and the newly born. What has become equally evident is that the nutriment the growing brain requires is affective and cognitive as well as alimentary. The extraordinary dependence of the human young upon adult care and caring provides both an unparalleled opportunity for mental and emotional development and a period of vulnerability to profound distortion by neglect (21). Infants in orphanages lag markedly in development, despite normal food intake, if denied a responsive human environment. There are indeed gaps in our knowledge of this early developmental sequence: just how much stimulation is optimal, just what balance is to be struck between gratification and denial, just what is the best mix between social interaction and time to be alone? Yet the outlines are clear enough to allow no excuse for what we permit to befall defenseless children, who suffer from the contumely we visit on their parents. Each infant differs from the others: no two, except for identical twins, share a common genome, and even identical twins may differ phenotypically because of gestational inequalities. We do not understand individual variability sufficiently well to fashion optimal environments for each child, but surely this does not mitigate our failure to provide at least those general requirements shared by all children (22).

Ignorance, as well as lack of commitment, becomes a limiting factor when children reach the years of formal education. The shortcomings of available theories of learning constrain our ability to respond to individual differences in the way children fashion their personalities and cognitive styles (23). There may be much to be gained from comparative studies of animal learning - to be sure, we are primates ourselves, but primates of a very special sort. We are no less usbject to classical and operant conditioning, to trial and error learning, and the like, but only we have the capacity for superordinate modes of verbal learning, and these require much deeper study than has been devoted to them. Our challenge is no longer transmitting solutions that have been successful in the past, but helping our children to acquire attitudes and sets for problem-solving that will enable them to meet undreamed-of challenges to their capacities.

We have done least well at the task of encouraging the development of humane values based upon the recognition that we are a single species. The idea of brotherhood is not new, but what is special to our times is that brotherhood has become the precondition for survival. It may have sufficed in the past to spur a child to learn for the sheer satisfaction of his own success. If we have listened to what our students are telling us, learning for personal embellishment or for the acquisition of virtuosity no longer satisfies a generation intensely aware of injustice and impermanence. Learning must become a social enterprise, informed by concern for others (24).

This it can become. Man is his own chief product. The infant who discovers that he can control the movements of his own fingers transforms himself from observer into actor. The child who masters reading unlocks the treasury of the world's heritage. The adolescent who insists upon a critical reexamination of conventional wisdom is making himself into an adult. And the adult whose concerns extend beyond family and beyond nation to mankind has become fully human.

By acting on behalf of our species we become men and women. In a world in which wars rage, in which repressive governments subjugate their peoples, in which the pursuit of personal affluence ravages an environment that must be shared by all, there can be no neutrality. Members of the university community carry a heavy measure of responsibility for the privilege accorded them; that responsibility is to pledge themselves to the service of man if knowledge is to be transformed into wisdom.

The study of man takes its meaning from involvement in the struggle for human betterment. Struggle it is and will be: privilege does not surrender easily; false belief is not readily dispelled. The optimism about man's potential I urge upon you is not the selfcomfort of reading history as a saga of progressive liberation which will one day be complete. It matters, and matters dearly, to Vietnamese and to Pakistani, to Americans and to Canadians, whether that day comes sooner or later; whether it comes at all is not determined by history but by the men 
and the women who make history. This has been eloquently stated by the Cuban poet Padilla, who has recently been released from prison in his own country. The final lines of his poem "Important Occasions" (25) read:

History's going to save us-we were thinking.

Going to save us-were we dreaming?

It wasn't all just uprisings, barricades, bonfires:

in our heads it was a dress of bubbling foam, a

Rhine maiden with clear eyes, smiling, standing

at the door, hand outstretched

toward a hungry and waiting people.

But there was no one in the doorway. Nor in the house.

Instead we stumbled. They shoved us inside. We broke our teeth going in, got our jaw smashed.

We found tools and weapons and we fought, we struggled, we worked and continued

fighting. But it's true, old Marx,

that History is not enough.

Important occasions,

man makes them.
It's a real, live man who does it, who masters it, who will fight.

History by itself does

nothing, dear friends.

It does absolutely nothing.

\section{References and Notes}

1. N. Wiener, Science 131, 1355 (1960).

2. Morris, The Naked Ape (McGraw-Hill, New York, 1967); R. Ardrey, African Genesis (Dell, New York, 1961); The Territorial Imperative (Dell, New York, 1966); K. Lorenz On Aggression (Harcourt, Brace \& World, New York, 1966).

3. S. Freud, Reflections on War and Death (Moffat, Yard, New York, 1918), p. 60

4. S. Freud, Civilization and Its Discontents (Hogarth, London, 1930), p. 102.

5. P. Pinel, A Treatise on Insanity, D. D. Davis, Transl. (Hafner, New York, 1962); G. Rosen, Madness in Society (Univ. of Chicago Press, Chicago, 1968); A. Deutsch, The Mentally Chicago, 1968); A. Deutsch, The Mentally Ill in America (Col
York, ed. 2, 1949):

6. E. M. Gruenberg, Amer. J. Orthopsychiat. 37, 645 (1967)

7. D. S. Lehrman in Development and Evolution of Behavior, L. R. Aronson, E. Tobach, D. S. Lehrman, J. S. Rosenblatt, Eds. (FreeD. S. Lehrman, J. S. Rosenblatt, Eds. (Free-
man, San Francisco, 1970); E. Tobach, L. R. Áronson, E. Shaw, Eds. The Biopsychology of Development (Academic Press, New York, 1971); L. R. Aronson, E. Telected Writings of $T$. C. Schneirla (Freeman, San Francisco, 1972)

8. K. Lorenz, Z. Angew. Psychol. Charakterkunde 59, 2 (1940).

9. J. P. Scott, Aggression (Univ. of Chicago Press, Chicago, 1958).

10. - Amer. J. Orthopsychiat. 40, 568 (1970).

11. J. B. Gurdon, Sci. Amer. 219, 24 (Sept.
1968); and H. R. Woodland, Biol. Rev. 43, 233 (1968)

12. R. A. Hinde, Ed., Bird Vocalizations (Cambridge Univ. Press, London, 1969).

13. M. Konishi and F. Nottebohm, in Bird Vocalizations, R. A. Hinde, Ed. (Cambridge Univ. Press, London, 1969), pp. 29-48.

14. P. C. Mundinger, Science 168, 480 (1970).

15. N. Chomsky, Language 35, 26 (1959); Language and Mind (Harcourt, Brace \& World, New York, 1968); J. Lyons, Noam Chomsky (Viking, New York, 1970).

16. S. Benzer, Proc. Nat. Acad. Sci. U.S. 58 , 1112 (1967); J. Amer. Med. Ass. 218, 1015 (1971); R. J. Konopka and S. Benzer, Proc. Nat. Acad. Sci. U.S. 68, 2112 (1971).

17. Y. Hotta and S. Benzer, Proc. Nat. Acad. Sci. U.S. 67, 1156 (1970).

18. M. D. Sahlins, Sci. Amer. 203, 76 (Sept. 1960).

19. J. L. Singer, Ed., The Control of Aggression and Violence (Academic Press, New York, 1971).

20. M. Winick, Pediatrics 47, 969 (1971); H. G. Birch and J. D. Gussow, Disadvantaged Children: Health, Nutrition and School Failure (Harcourt Brace Jovanovich, New York, 1970); H. G. Birch, C. Pineiro, E. Alcade, T. Toga, J. Cravioto, Pediat. Res. 5, 579 (1971).

21. L. Eisenberg, in The Social Responsibility of Gynecology and Obstetrics, A. C. Barnes, Ed. (Johns Hopkins Press, Baltimore, 1965), pp. 53-79.

22. B. M. Caldwell, Amer. J. Orthopsychiat. 37, 8 (1967); L. Eisenberg, ibid. 39, 389 (1969)

23. S. H. White and H. D. Fishbein, in Behavioral Science in Pediatric Medicine, M. Talbot, J. Kagan, L. Eisenberg, Eds. (Saunders, Philadelphia, 1971), pp. 188-227.

24. L. Eisenberg, Science 167, 1688 (1970); K Kenniston, Amer. J. Orthopsychiat. 40, 577 (1970); S. E. Luria and Z. Luria, Daedalus 99, 75 (1970).

25. H. Padilla, "Important Occasions," P. Blackburn, Transl., N.Y. Rev. Books (3 June 1971), p. 5 .

\title{
Circumscribed Halos
}

\section{Circumscribed halos which appear around the sun are simulated by a computer treatment of a simple model.}

\author{
Robert G. Greenler and A. James Mallmann
}

Ice crystals in the atmosphere are responsible for a variety of optical phenomena in the sky. One of the most familiar of these phenomena is a circle of light around the sun, with an angular radius of $22^{\circ}$, as shown in Fig. 1. This

Dr. Greenler is professor of physics at the University of Wisconsin-Milwaukee, Milwaukee 53201. Until September 1972, he is on leave at the School of Chemical Sciences, University of East Anglia, University Plain, Norwich NOR East Anglia, University Plain, Norwich fessor of physics at the Milwaukee School of Engineering, Milwaukee, Wisconsin 53201. halo results from sunlight deviated by about $22^{\circ}$ by refraction through randomly oriented hexagonal ice crystals. Occasionally this $22^{\circ}$ halo is circumscribed by another halo which is tangential to the $22^{\circ}$ halo at the top and bottom. Unlike the circular $22^{\circ}$ halo, the shape of the circumscribed halo varies markedly with the altitude of the sun (as can be seen in Fig. 7). In this article we analyze the source and form of this circumscribed halo.

\section{The Model}

Ice crystals in the air commonly exist in the form of hexagonal prisms. If the length of the crystal along the axis is short as compared with its width, the crystal will have the form of a flat hexagonal plate. If the axial dimension is long, the crystal will have the shape of a hexagonal column which we refer to as a pencil crystal, after its resemblance to the shape of the common wooden pencil. These crystals, falling in still air, tend to assume the orientation which provides maximum air resistance. This means that flat plate crystals will tend to fall with their axes vertical and the pencil crystals with their axes horizontal. The details of the orientations of a group of falling ice crystals will determine the pattern of light in the sky which results from sunlight refracted by these crystals. Our approach has been to calculate the path of light rays through a distribution of ice crystals in order to find that distribution which produces the observed forms of the circumscribed halo. 